DOI https://doi.org/10.18551/rjoas.2018-09.02

\title{
ANALYSIS OF POT MEETS POP'S MARKETING STRATEGY WITH PERCEPTUAL MAPPING APPROACH: A STUDY ON MEN'S JEANS CONSUMERS IN JAKARTA
}

\author{
Alfisyahr Rizal*, Pamungkas Henry \\ Faculty of Administrative Science, University of Brawijaya, Indonesia \\ *E-mail: rizal.alfisyahr@ub.ac.id
}

\begin{abstract}
This study aimed to explain the customer perception on male jeans market and use the data from the research to formulate marketing strategy for Pot Meets Pop jeans brand in order to compete with its competitors in especially in Jakarta. The type of this study is descriptive research with quantitative approach. Data were gathered from a survey of 150 male respondents aged between 17-40 in Jakarta. The sampling technique for this research was using convenience sampling and the data collecting method by distributing offline questionnaire. Data analysis used descriptive analysis and multidimensional scalling (MDS).
\end{abstract}

\section{KEY WORDS}

Perceptual mapping, marketing, strategy, men's fashion.

The development of the fashion industry has been growing very rapidly. This can be seen from the increasing number of sales of each manufacturer and supported by a change in the social minds of fashion that is worn not only as a body cover and ornaments, more than that also become a means of communication as a determinant of attitudes, values, wealth, and social position. So the demand for the needs and diversity of fashion becomes increase from year to year. The increasing economic condition of the society is also a factor triggering the rise in the numbers.

Based on The Indonesian Textiles and Apparel Community reference, the market value offered by the inustry can be very tempting. It is reasonable considering that the textile and fashion industries are the primary needs of Indonesian society, although the purchasing power is not as big as Singapore. The market value of textile and fashion products industry in 2015 is estimated to reach US \$ 15.19 billion.

In 2016, Indonesian Central Bureau of Statistics indicated that the Creative Economy sector contributed $7.38 \%$ to the total national economy in 2016 , which dominated by three subsectors (culinary, fashion, and craft). Further, the fashion sector contributed as much as $18.15 \%$ or number two after culinary. Disclosure of the results, indicating that fashion has become one of the drivers of Indonesia's creative economy.

One of the fashion attributes that are popular all over the world is denim. At first jeans is a trouser for the purposes of the navy, but as the age of jeans developed into a fashion product that can be worn by everyone (Hegarty, 2012). Cause of jeans is one of the fashion attributes that always favored from various circles and timeless, a trend pants always grow, unique, and enthused in the society, and easy to find in stores that make interested in the world of fashion industry competition. Thus making the author's reason to takes the topic of jeans as a topic in fashion marketing research.

The city of Jakarta, as the capital of the State of Indonesia and a business center in Indonesia which became a barometer of competition in the creative industry. Small to large scale local brands are popping up day by day. Various innovations and alternatives from different fields are combined to produce the best quality to enhance market advantage. In Jakarta, customer can easily find the famous jeans brand from local to international brand and also can found most of the jeans store easily, thus providing many alternatives for consumers to be able to choose the desired product according to taste, purchasing power and of course put the quality. It certainly requires every entrepreneur to give more value than any product creates to win the competition in the industry. Thus making Jakarta as a city for the development of a fashion including jeans industry. As the jeans industry grew, local 
entrepreneurs began to develop their own brands. Not only oriented to domestic market, but also began to build an international brand. Many local brands emerge and create new kind of product that can differentiate themselves from the others, in order to compete with renowned global brands, namely: Mischief denim divisions, Pot Meets Pop, Elhaus, Aye denim, Old Blue co, etc.

This research focus on Pot Meets Pop as an object, in order to get a local jeans brand perspective to survive in the industry which mostly held by international brand such as; Levis, Wrangler, Lee Cooper, and others. Pot Meets Pop known as the originator of local jeans brands that use raw materials denim as a new thing in the jeans market in Indonesia, but its existence did not show a very significant progress during the 10 years this brand stands. It was first launched into the market in March 2009. Since then, they consistantly support local underground communities as a brand collaboration strategies.

Seeing above the phenomenon as the rapid development and the enthusiasm of fashion especially jeans in Indonesia. Company need tho think strategically and understand more about their consumers and competitors. In this study researcher use perceptual mapping in order to understand consumer perception of its brand among its current competitors. According to Gower et al. (2010), perceptual mapping are often used in marketing to visually study the relationship between two or more attributes and represent a visual representation of the respondent's perception of an object in two or more dimensions. Meanwhile, according to vigner and Iskandar (2014) states positioning maps are defined as a diagram that is used to try to show a perception of consumers or potential consumers of a brand and its competitors. Where positioning map will show consumer perception in important purchasing dimension. One that can be used to measure perception is the product attribute. Attributes in perceptual mapping are dimensions of a product that define a given purchasing experience and represent consumer ratings of product and purchase decisions.

\section{LITERATURE REVIEW}

Marketing Strategy. According to Kotler and Armstrong (2004: 45) marketing strategy is the marketing logic where the business unit hopes to create value and benefit from its relationship with consumers. Before designing a marketing strategy, a review of the future business situation needs to be undertaken. The SME concept is known as 4C Diamond consisting of Change, Customer, Company and Competitor (Kartajaya, 2014). The first of three factors are the main elements of the business landscape that is an external factor that must be continuously observed because as it is formulated in its marketing philosophy. Marketing is an "outside-in" approach, rather than "inside out". While the last factor of the Company, is the internal factors of the company that are very critical of its position in strategy development. The Change (environment), Customer, and Competitor studies generate an outlook on the future business landscape. Insight gained from external changes are things that can threat and also bring new opportunities for internal company. After analyzing the three of "C", then marketers look inside the company, various aspects related to weaknesses and strengths in the midst of landscape changes.

Positioning in Strategic Marketing. Positioning are known as how customers compare a specific product, service, or brand in relation to competitors. Ries and Trout (1981) explained that the concept of positioning is essentially positioning the product in the customer's mind. For many years marketers understand that a way to succesfully do that through a clear and consistent image-building campaign. Based on the evidence, many studies (Gardner and Levy, 1955; Park et al., 1986) have recommended that developing, communicating, and maintaining a brand's image is important to its long-term success.

Brand Image. Brand image is generally identified all things related to the brand that is in the minds of consumer memory. According to Kotler and Keller (2009:259) Brand Image as the total number of brand associations that consumers have as a memory that leads to brand perceptions. According to Schifman and Kanuk (2010), brand image is a long-lasting perception, shaped through experience, and has a relatively consistent nature, and therefore consumer attitudes and actions toward a brand image is an important element which 
encourages consumers to buy a product. Based on the description can be concluded that a good brand image will have a positive impact on consumer behavior on the brand, such as the opportunity to obtain more loyal buyers.

Brand Awareness. According to Assael and Day (1968) Brand Awareness is the level at which customers are aware of the brand and become part of the brand. Brand awareness has four levels of unware brand, brand recognition, brand recall, and top of mind. According to Macdonald and Sharp (2003), Brand Awareness is the point of view of how consumers associate brands with specific products that they aim to have, brand awareness is indispensable for communication as a process to raise awareness of top of the mind.

\section{METHODS OF RESEARCH}

The analytic techniques for the study were descriptive statistics and multidimensional scaling (MDS). Descriptive statistics where used to profile the respondent including brand most buying frequency, brand top of mind and brand recall. MDS where use to create a perceptual mapping of male jeans consumer. MDS is "a procedure that allows a researcher to determine the perceived relative image of a set of objects" (Hair et al., 1998). Through MDS, this study can portrait how consumer perceive the brands from one an another based on specific attributes.

There are 14 attribute that were used in multidimensional scalling, adapted from BLI scale that developed by Vigneron and Johnson (2004) to identify components of consumer luxury brand perceptions. The BLI scale are also known as an instrument to address concerns about luxury brands mentioned by Cailleux et al. (2009), Wiedmann et al. (2007), Keller (2009) and Doss and Robinson (2013).

This research was conducted in Jakarta, using a convenience sampling of male jeans users. A total of 150 questionnaires were completed; four were discarded because they were incomplete. Each respondent completed a separate modified BLI scale for the male jeans brand, and the counterfeits of that brand.

\section{RESULTS AND DISCUSSION}

In this study, researchers collected 52 brands, and compressed the results into 10 jeans brands in Jakarta with the most frequently purchased. Pot Meets Pop brand where placed in the ninth order between them all. The result of this research is then processed using multidimensional scale in the form of perceptual mapping. Perceptual Mapping is the basis of reference researchers in analyzing the brand positioning of Pot Meets Pop with its competitors.

Multidimensional Scalling data processing results in the form of map position 10 brands of men's jeans show the position of the brand of Pot Meets Pop with its competitors are different. Perceptual mapping also shows that each of the dominant attributes of a brand is based on the ecludiean distance on each attribute and brand. Pot meets pop is in first quadrant with negative value on dimension 1 and positive value in dimension 2 . In the same quadrant one, there are H\&M and Wrangler jeans that perception of consumer as the nearest competitor from Pot Meets Pop with the proximity attribute of unique, young, and cool.

The result shows the closest competitor of Pot Meets Pop is H\&M brand in the same quadrant 1 with the same attribute. Followed by Wrangler, Lee Cooper, Lois, Lea, Nevada, Zara, Pull\&Bear and Levi's. Pot Meets Pop has a unique attribute that is very dominant according to consumer perception with the distance of euclidean distance of 0.9 and perceived very close to this attribute in one quadrant followed by H\&M jeans. Then for the other closest attributes of the brand Pot Meets Pop are young attributes and cool attributes, although Pot Meets Pop still lost behind the H\&M jeans. H\&M jeans brands are perceived to be very close to the young and cool attributes because they have the closest Euclidean Distance compared to other brands. Therefore it can be concluded that the unique attributes on Pot Meets Pop jeans are the most powerful compared to other jeans brands. 
H\&M jeans brand is the closest competitor of the Pot Meets Pop based on consumer perceptions and euclidean distance values. It can be called as the head to head brand from Pot Meets Pop competitors. H\&M jeans brand are competing with Pot Meets Pop that occupies the top spot in unique, young and cool attributes that are in fact very close to H\&M and Pot Meets Pop, but have slightly different target markets. Pot Meets Pop is more targeted to the market for consumers who like raw jeans, while H\&M is targeting consumers who like ordinary washed jeans that easily found in shopping centers. This is also evident from frequent brand frequencies in respondents where Pot Meet Pop is ranked 9th and H\&M are ranked 4th. Strategies that can be applied is strengthen the characteristics of the cool and young image, but still put forward the power of the character Pot Meets Pop that is attached that a unique attribute.

After knowing the position of Pot Meets Pop brand in perceptual mapping by looking at attributes and its closest competitors, researchers conducted market analysis through the frequency of selling the most commonly purchased jeans by consumers (most buying) in the city of Jakarta.

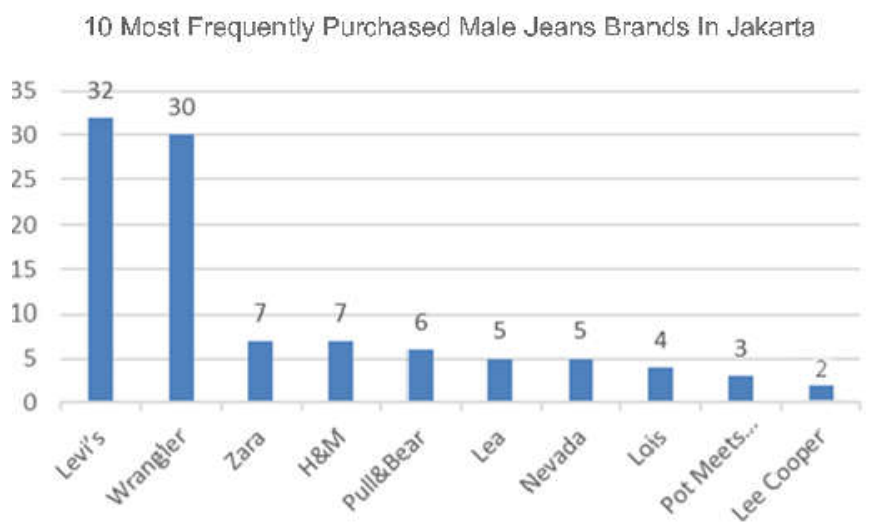

Figure 2 - Frequently Purchased Jeans Brand In Jakarta (Source: primary data processed, 2018)

Researcher find out the number of product purchases from the top ten brands of jeans based on indicators. So it can facilitate researchers in analyzing the number of items sold in each product to determine the level of competition and grouping of each zone to the brand inside.

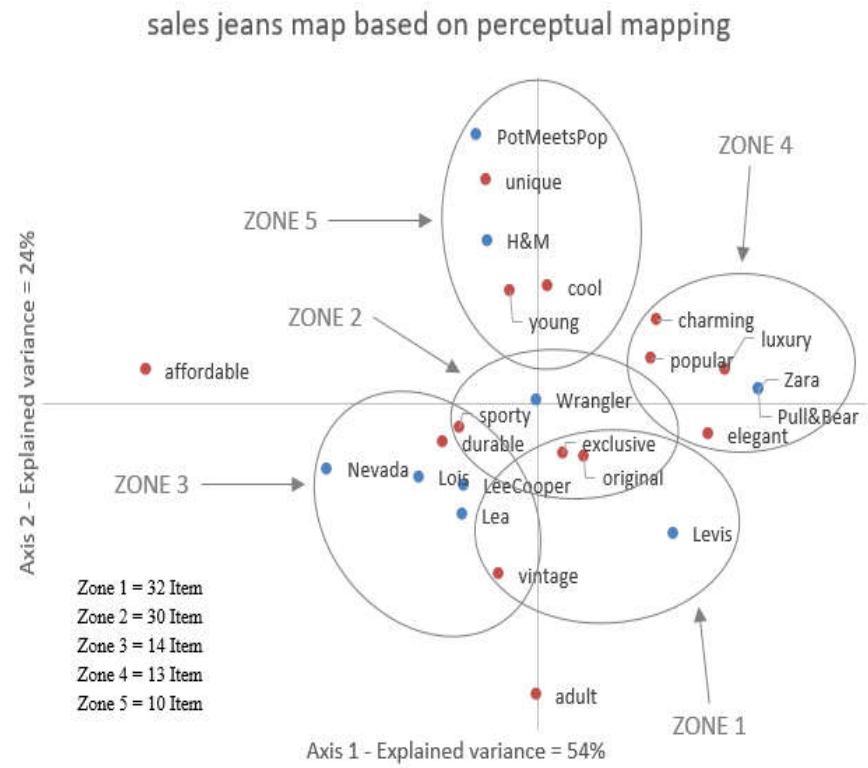

Figure 3 - Sales jeans map based on perceptual mapping (Source: processed by researcher, 2018) 
Figure 3 shows a sales map of jeans brands that match the top ten brands perceptual mapping results based on frequent brand frequencies and indicators. These results provide an appropriate strategy analysis according to the researchers to the brand of Pot Meets Pop jeans against its competitors and grab another zone as a new market. These brands are scattered in several groups of brands and attributes that are close together in a zone using the closest competitor of each brand.

In zone 1 it appears that there are only Levi's jeans with original, elegant and exclusive attributes with the total sales of thirty-two items of jeans sold. Zone 1 is a testament to the strength of the brand that is very embedded in the minds of consumers of jeans in Indonesia, especially in the city of Jakarta that brand levi's always excel in the category of Top of Mind, Most Buying, Most Favorite and is on the order of brand recall. Similarly, the closest competitor Levi's brand Wrangler is located in zone 2 with the total sales of thirty items. In fact in the market, indeed Levi's and Wrangler is very superior to the jeans industry in the world because it is Levi's and Wrangler as a brand originator of jeans and can survive until today. So Levi's and Wrangler can be a role model by other brand jeans to learn them strategy with the proximity of original attributes, elegant, sporty, and exclusive how to superior in jeans industry in Indonesia.

While the third zone there are jeans brand Lois, Nevada, Lea and Lee Cooper with the attributes of Sporty, Durable, and Vintage with the number of sales of jeans as many as fourteen items. In the fourth zone there are Zara and Pull \& Bear jeans that have luxurious, popular, elegant, and captivating attributes with a total of thirteen items valued by both zones as a safe zone.

Pot Meets Pop jeans is in the fifth zone where there are only Pot Meets Pop and H\&M jeans with unique, young, and cool attributes in this group with a total of ten items. This shows that Pot Meets Pop jeans are in an unsafe zone in Indonesian jeans industry in Jakarta market, when juxtaposed with top ten brands of top jeans based on consumer perception with the number of Pot Meets Pop jeans sales in this fifth zone only as many as three items or can with the smallest contribution. Pot Meets Pop is a new jeans brand for jeans users in Indonesia, just a local indie brand by using unusual materials on the market such as international brands such as Levi's, Wrangler, Lois, H\&M, Zara and others.

Looking from perceptual mapping, the position of Pot Meets Pop zone farthest away from the crowded jeans market and very different from other mass jeans market. With the concept of selling a limited product that will not release the same product in the following season's articles, highly segmented jeans come from jeans with raw denim materials lover that close to the darahkubiru community, and the product focuses on raw denim materials, making Pot Meets Pop into a niche market. Kotler (2003) defines a niche as a more narrowly defined group seeking a distinctive mix of benefits. He states that niche markets are usually identified by dividing a segment into subsegments and that the key issue in niche marketing is specialization, and also explains the main reason why a niche market strategy is so profitable is that the specializing firm ends up knowing the customers so well that it is able to better meet their needs. As a result, the firm can charge a substantial price over costs and achieves high margins, whereas the mass-market firm achieves high volume (Kotler, 2003). Besides profits, there are other reasons firms implement a niche market strategy. By focusing on the customer, the firm is better able to respond faster to demand changes.

Based on the researchers data, theory, and market reality. Pot Meets Pop needs to apply niche market strategy with a focus on segmented consumers by spoiling them with the superiority of using raw denim materials. So it is able to better meet their needs and can charge a substantial price over costs and achieves high margins as the result. So Pot Meets Pop does not need to get out of the zone and take the already crowded jeans market, but still focus in its own market. Once it is felt the market is saturated and achieve maximum sales on the target, and also force Pot Meets Pop to be ready to take a crowded jeans market zone. Pot Meets Pop needs to prepare larger capital for mass products, wider distribution channels, and be ready to compete with big competitors. The first step to take a more crowded market is to see the head to head competitors that are in the same zone that is H\&M. 
The good things that Pot Meets Pop can consider to market expand in other jeans market zone that is seen from consumer perception. Data of consumer perceptions shows that Pot Meets Pop has a good position among other jeans competitors that is ninth ranked on the basis of the indicators that have been researched. To further strengthen the strategy that Pot Meets Pop should apply first, the researchers will analyze the characteristics of Pot Meets Pop consumers that compare with H\&M as head to head competitors and all jeans brands in Jakarta based on sales data from most buying categories. Characteristics of consumer jeans Pot Meets Pop in the city of Jakarta can be seen in Table 1.

Table 1 - Characteristics of Pot Meets Pop Consumers with Competitors

\begin{tabular}{|c|c|c|c|c|c|c|}
\hline \multirow{2}{*}{ No } & \multirow{2}{*}{ Characteristic } & \multirow{2}{*}{ Amount of Jeans Sales in Jakarta } & \multicolumn{2}{|c|}{ H\&M Consumers } & \multicolumn{2}{|c|}{ Pot Meets Pop Consumers } \\
\hline & & & Item & $(\%)$ & Item & $(\%)$ \\
\hline 1. & $\begin{array}{l}\text { Age: } \\
17-21 \\
22-26 \\
27-31 \\
32-40 \\
\end{array}$ & $\begin{array}{l}86 \\
44 \\
13 \\
7 \\
\end{array}$ & $\begin{array}{l}4 \\
3 \\
0 \\
0 \\
\end{array}$ & $\begin{array}{l}2.6 \\
2 \\
0 \\
0 \\
\end{array}$ & $\begin{array}{l}3 \\
0 \\
0 \\
0 \\
\end{array}$ & $\begin{array}{l}2 \\
0 \\
0 \\
0 \\
\end{array}$ \\
\hline \multicolumn{2}{|c|}{ Total } & 150 & 7 & 4.6 & 3 & 2 \\
\hline 2. & $\begin{array}{l}\text { Marital Status: } \\
\text { Married } \\
\text { Single }\end{array}$ & $\begin{array}{l}25 \\
125 \\
\end{array}$ & $\begin{array}{l}1 \\
6 \\
\end{array}$ & $\begin{array}{l}0.6 \\
4 \\
\end{array}$ & $\begin{array}{l}0 \\
3 \\
\end{array}$ & $\begin{array}{l}0 \\
2 \\
\end{array}$ \\
\hline \multicolumn{2}{|c|}{ Total } & 150 & 7 & 4.6 & 3 & 2 \\
\hline 3. & $\begin{array}{l}\text { Profession: } \\
\text { Student } \\
\text { Employees } \\
\text { Professional } \\
\text { Unemployee }\end{array}$ & $\begin{array}{l}99 \\
34 \\
11 \\
6 \\
\end{array}$ & $\begin{array}{l}6 \\
1 \\
0 \\
0 \\
\end{array}$ & $\begin{array}{l}4 \\
0.6 \\
0 \\
0 \\
\end{array}$ & $\begin{array}{l}3 \\
0 \\
0 \\
0 \\
\end{array}$ & $\begin{array}{l}2 \\
0 \\
0 \\
0\end{array}$ \\
\hline \multicolumn{2}{|c|}{ Total } & 150 & 7 & 4.6 & 3 & 2 \\
\hline 4. & $\begin{array}{l}\text { Household Income: } \\
<2 \text { million } \\
2-4 \text { million } \\
4-6 \text { million } \\
6-8 \text { million } \\
>8 \text { million }\end{array}$ & $\begin{array}{l}76 \\
39 \\
18 \\
7 \\
10\end{array}$ & $\begin{array}{l}4 \\
3 \\
0 \\
0 \\
0\end{array}$ & $\begin{array}{l}2.6 \\
2 \\
0 \\
0 \\
0\end{array}$ & $\begin{array}{l}3 \\
0 \\
0 \\
0 \\
0\end{array}$ & $\begin{array}{l}2 \\
0 \\
0 \\
0 \\
0\end{array}$ \\
\hline Tota & & 150 & 7 & 4.6 & 3 & 2 \\
\hline
\end{tabular}

Source: processed by researcher, 2018.

Table 1 above shows that the characteristics of jeans consumers in the city of Jakarta are dominated by young age between 17 to 21 years old who status as unmarried students from highchool and college that only have income less than two million rupiah. This shows that the jeans market in Jakarta is in great demand by young people or students.

The results of consumer characteristics in table 1 shows that the jeans market in the city of Jakarta is the young age is very in accordance with consumers of the brand Pot Meets Pop with the characteristics of brand attributes are unique, young, and cool. Young consumers choose Pot Meets Pop because of the unique superiority of attributes offered, where the use of raw denim material that can evolve based on activity usage becomes a trend at the moment and is perfect with the style of young people who want to look different and look more cool than others. The attributes offered are also considered to have different social values for younger consumers. If you have been using a product especially jeans that are considered in accordance with the fashion trends and social values that exist then the consumer will be more confident or feel a jeans brand feel able to show their identity. Then coupled with the marriage status that is not married is likely to make a young consumer is more literate to fashion and still in the process of looking for a style or fashion that has the attributes in accordance with his want.

According to Jegethesan et al. (2016) that young consumers consider purchasing decisions because of the appropriate attribute ethics offered on a product. According to Dickson in the same journal mentioned that social value is also a consideration in making purchasing decisions of fashion products on young consumers. This opinion reinforces the 
reason that unique attributes represent more value in the Pot Meets Pop jeans that match the characteristics of young consumers at the moment.

Other consumer characteristics of Pot Meets Pop's jeans consumers are job status dominated by students and household income dominated by a range of numbers under two million rupiah. This shows that Pot Meets Pop jeans match the needs of students who are not required to wear formal trousers for a day's work a day and in accordance with the current student style where the design and cut the model of jeans that suit and have student ethics because it can be used at any time, both at college and at other moments. The price of Pot Meets Pop with a range of five hundred and fifty thousand to one million rupiah is also in accordance with the household income seen in Pot Meets Pop consumers. This shows that the price of Pot Meets Pop jeans is still in the price category that can be reached by consumers, as well as seeing the period of the use of jeans long enough shows that with household income under two million rupiah is very possible consumer Pot Meets Pop to buy it.

Looking from H\&M as head to head brand of the closest competitor from Pot Meets Pop is not much different. H\&M has gained a market among adult married age and has a formal job. So Pot Meets Pop needs to introduce its brand to other market not only among young people but also the mature age and middle class, larger capital for mass products, and wider the distribution channels. Besides of improve the product quality and closer the characteristics of other brand attributes or product value offered to consumers. Pot Meets Pop need to increase brand awareness with the campaign to introduce the superiority of materials used to increase the sales and dominate the market to grab the crowded jeans market zone.

Pot Meets Pop needs to do a strategy in introducing its brand to jeans consumers in Indonesia in order to achieve category top of mind, most buying, most favorite, and brand recall like Levi's and Wrangler. The most effective strategy for Pot Meets Pop is to further improve the marketing through communication channels, such as mobile phones through online maketing in website and social media that are on the rise nowadays and seen the jeans consumers characteristics that dominated by young age people to get a positioning in the minds of consumers of jeans in Indonesia. This strategy is consistent with Sasmita and Suki (2015) that consumers receive brand awareness through effective marketing channels such as telecommunications, mobile telephones and online advertising that provide quality assurance and product credibility where it will reduce the risk to products selected when performing a product.

This strategy is also supported by items on buying preference that need to be considered and highlighted by the company to support marketing activities in the market competition. In the data it appears that consumer preference prioritize are prices, product quality and brand. This consumer priority should also be prioritized by Pot Meets Pop jeans to win the market. This is believed by researchers as a long-term strategy that will impact on direct and indirect profits with the company. Besides of Pot Meets Pop have to learn the characteristics of each brand contained from each zone attributes such as original, elegant, charming, luxury, exclusive, popular, vintage, durable, and sporty. But still based on the characteristics of the brand Pot Meets Pop itself with unique, young, and cool attribute. So Pot Meets Pop can slowly enter each zone to expand the market and increase the sales.

\section{CONCLUSION AND SUGGESTIONS}

Pot Meets Pop (PMP) brand on the perceptual mapping is at coordinate 15 in dimension 1 and coordinates 49 in dimension 2. This brand is in quadrant 1 along with $\mathrm{H} \& \mathrm{M}$ and Wrangler jeans. These three brands are perceived by consumers to have similarities or similar product attributes and have no significant difference compared to other brands.

Consumers consider PMP as unique brand, they were also perceive as young and cool. The closest competitor for them in this attribute is $H \& M$, where the brand perceived as younger and cooler. It can be said that H\&M is the closest competitors to PMP. 
Based on the perceptual mapping, PMP where placed farthest from the other jeans brand. That make this brand very unique with a niche market selection. With the the concept of selling a limited product and focuses more on raw denim materials, PMP doesn't need to get out of the zone and take the already crowded jeans market. The brand should stay focused on working on their own selected market in order to be able to meet their customer needs, and charge a substantial price over costs and achieves high margins as the result.

The characteristics of jeans consumers in Jakarta city in this research is dominated by young age as a student who has unmarried status and has household income under two million rupiah. The results shows that consumers of Pot Meets Pop is very suitable with the characteristics of jeans consumers who are young age with the proximity attributes of unique, cool, and young. H\&M as the head to head brand of the nearest competitor Pot Meets Pop shows the results are not much different. H\&M has gained a market among adult married age and has a formal job. So Pot Meets Pop needs to introduce its brand to other market markets not only young age but middle-class, larger capital for mass products, and wider the distribution channels, as well as improving product quality and bringing together other brand attribute characteristics or product value offered to consumers. So as to increase the sales and dominate the market to grab the crowded jeans market zone.

Suggestions:

Researcher suggest to further researcher to more explore for reference in determining the attributes and adjust to the existing conditions in the object of research, so that the expected results will be better research and consumer perceptions will be more diverse.

To further illustrate the jeans brand competition, it is advisable that further researcher more expand the scope of the study. Not only limited to product attributes, so that it can describe the competition nationally and internationally by involving respondents in big cities and involve more brands, both domestic and international.

\section{REFERENCES}

1. Assael, H and Day, G. S. 1968. Attitudes and Awareness as Predictors of Market Share. Journal of Advertising Research, Vol. 8 No. 4, pp. 3-10.

2. Cailleux, H., Mignot, C. and Kapferer, J. (2009), "Is CRM for luxury brands?", Journal of Brand Management, Vol. 16 Nos 5/6, pp. 406-412.

3. Doss, F and Robinson, T. (2013),"Luxury perceptions: luxury brand vs counterfeit for young US female consumers", Journal of Fashion Marketing and Management: An International Journal, Vol. 17 Iss 4 pp. 424 - 439

4. Gardner, B.B. and Levy, S.J. (1955), "The product and the brand", Harvard Business Review, March-April, pp. 33-40

5. Gower, J.C, Groenen, P.J.F, van de Velden, M, \& Vines, K. 2010. Perceptual Maps: The Good, The Bad and The Ugly. ERIM report series research in management Erasmus Research Institute of Management. Erasmus Research Institute of Management.

6. Hair, J. F., Anderson, R. E., Tatham, R. L., \& Black, W. C. (1998). Multivariate data analysis (5th ed.). London: Prentice-Hall International

7. Hegarty, S. 2012. "How Jeans Conquered The World". Retrieved on April $5^{\text {th }} 2018$ from http://www.bbc.com/news/magazine-17101768.

8. Jegethesan, K., Sneddon, J. N., Soutarm, G. N. 2012. Young Australian Consumers' Preferences for Fashion Apparel Attributes. Journal of Fashion Marketing and Management: An International Journal, Vol. 16 Issue: 3, pp. 275-289.

9. Kartajaya, H. 2014. Marketing In Challenging Times (Edisi Pertama). Jakarta: PT. Gramedia Pustaka Utama.

10. Keller, K.V. (2009), "Managing the growth trade-off: challenges and opportunities in luxury branding", Journal of Brand Management, Vol. 16 Nos 5/6, pp. 290-301.

11. Kohli, L. 2001. Equity: Capitalizing On Intellectual Capital. Ivey Business Journal. Brand 65 (4): $75-81$.

12. Kotler,P. (2003). Marketing Management, 11th Edition.Prentice. Hall.Inc.New Jersey. 
13. Kotler, P., and Keller, K. L. (2009). Marketing management. Upper Saddle River, N.J: Pearson Prentice Hall. Chicago

14. Kotler, P., Armstrong, G. 2004. Principles of Marketing. 10th Edition, Pearson-Prentice Hall, New Jersey

15. Macdonald, E and Sharp, B. 2003. Management Perceptions of The Importance of Brand Awareness as An Indication of Advertising Effectiveness. Marketing Bulletin, Vol. 14 No. 2, pp. 1-11.

16. Matthiesen, I and Phau, I. 2010. Brand Image Inconsistencies of Luxury Fashion Brands: A Buyer-Seller Exchange Situation Model of Hugo Boss Australia. Journal of Fashion Marketing and Management: An International Journal, Vol. 14 Issue: 2, pp. 202-218.

17. Ries, A., and Trout, J. (1981). Positioning: The battle for your mind. New York: McGrawHill.

18. Park, C.W., Jaworski, B.J. and Maclnnis, D.J. (1986), "Strategic brand concept image management", Journal of Marketing, Vol. 50, October, pp. 135-45.

19. Prasetya, C and Iskandar, BD. 2014. Perceptual Map Of Online Fashion Store. Journal of Business and Management. Vol. 3, No. 4, 2014: 432 - 439.

20. Sasmita, J and Suki, NM. 2015. Young Consumers' Insights on Brand Equity: Effects of Brand Association, Brand Loyalty, Brand Awareness, and Brand Image. International Journal of Retail \& Distribution Management, Vol. 43 Issue: 3, pp.276-292.

21. Schiffman, L.G., and Kanuk, L.L. (2010). Consumer Behaviour (10th ed). New Jersey, Pearson Prentice Hall

22. Vigneron, F. and Johnson, L.W. (2004), "Measuring perceptions of brand luxury", Journal of Brand Management, Vol. 11 No. 6, pp. 484-506.

23. Wiedmann, K., Hennigs, N. and Siebels, A. (2007), "Measuring consumers' luxury value perception: a cross-cultural framework", Academy of Marketing Science Review, Vol. 7 